\title{
COMUNICACÕES
}

\section{First record of rust caused by Puccinia psidii (Pucciniaceae) in Acmena smithii in Brazil}

\author{
Cristiane de Pieri $^{1}$, Edson Luiz Furtado ${ }^{1}$ e Martha Maria Passador ${ }^{2}$
}

${ }^{1}$ Universidade Estadual Paulista (UNESP), Departamento de Ciências Florestais, Faculdade de Ciências Agronômicas. R. José Barbosa de Barros, 1780, Cep. 18600-000, Botucatu, São Paulo, Brasil. ${ }^{2}$ Universidade Estadual Paulista (UNESP), Departamento de Produção Vegetal, Defesa Fitossanitária. Faculdade de Ciências Agronômicas. R. José Barbosa de Barros, 1780, Cep. 18600-000, Botucatu, São Paulo, Brasil.

Autor para correspondência: Cristiane de Pieri (pieri_cris@yahoo.com.br)

Data de chegada: 28/08/2015. Aceito para publicação em: 13/06/2016.

$10.1590 / 0100-5405 / 2122$

The species Acmena smithii belongs to the family Myrtaceae, which comprises around 140 genera and over 3000 species spread across the Americas and Australia (Joly, A.B.; Botânica: Introdução à taxonomia vegetal. 13a ed. São Paulo, Companhia Editora Nacional, 2002, 778p). Approximately 15 species belong to the genus Acmena, of which six occur in Australia. This relatively recent genus, originated from the division of the genera Eugenia and Syzygium, is widely distributed throughout humid subtropical forests of the east coast of Queensland [ANPSA. Australian Society of native plants, available at http://www. asgap.org.au/a-smi.html (2010) verified April 2010].

Commonly known as "mini-jambo-rosa" or "Lili-Pili", Acmena smithii (Poir.) Merr. \& Perry is a medium- to large-sized semi-deciduous tree which may reach from 4 to $20 \mathrm{~m}$ height and has been largely used as an ornamental plant and for urban afforestation [Lorenzi, H.; Bacher, L.; Lacerda, M.; Sartori, S. Frutas Brasileiras e Exóticas Cultivadas (de consumo in natura), Instituto Plantarum, 2006].

Affected Acmena smithii plants were found in the greenhouse of the School of Agronomical Sciences, Unesp - Botucatu Campus, São Paulo State, in September 2009, and the infection repeated in the same periods from 2010 to 2015 .

Voucher specimens of Acmena smithii plants were sent to Plantarum Institute for confirmation of the species. Thus, leaf samples with symptoms and signs on both the abaxial (Fig. $1 A$ ) and the adaxial surface (Fig. $1 B$ and $C$ ) were collected and taken to the Laboratory of Forest Pathology of the same institution, where they were observed under stereomicroscope and microscope. The pathogen was identified as

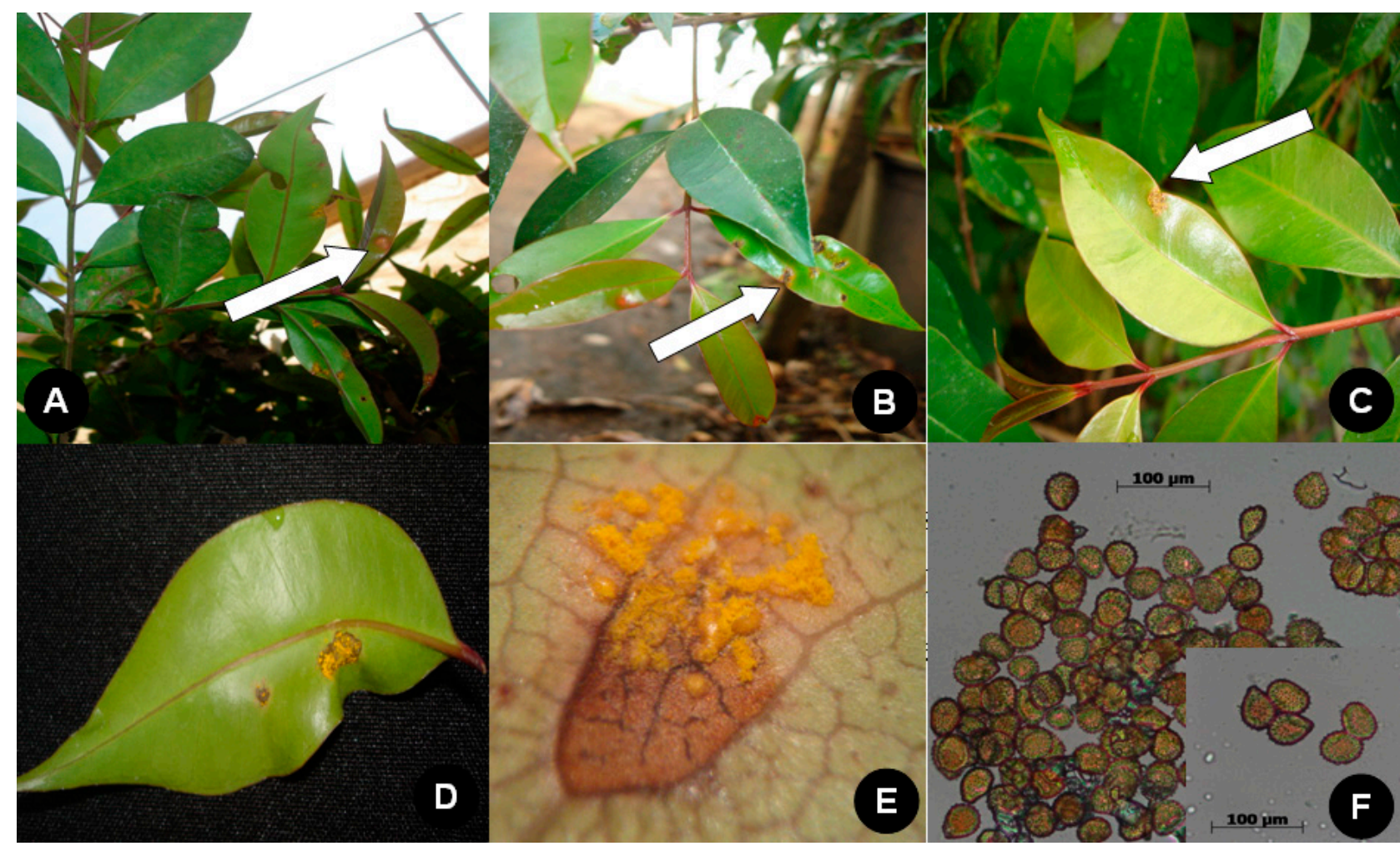

Figure 1. Puccinia psidii on Acmena smithii. $(A)$ Rust symptoms on the abaxial surface. $(B)(C)$ Rust symptoms on the adaxial surface. $(D)$ Symptoms observed in the pathogenicity test. $(E)$ Pustules under stereomicroscope. $(F)$ Urediniospores. 
a basidiomycete of the order Uredinales, Puccinia psidii, a pathogenic species.

Puccinia psidii Winter was found in Brazil by Winter in 1884 in plants of Psidium pomiferum L. (Maclachlan, J.D. A rust of the pimento tree in Jamaica, Phytopathology, v. 28, p.157-170, 1938). Since then, this basidiomycete was found attacking several species within the family Myrtaceae (Ferreira, F.A. Ferrugem do eucalipto. Revista Árvore, v. 7, p. 91-109, 1983). This fungus is native to South America and is largely distributed across South America and the Caribbean islands; there are also reports of its presence in other countries such as Jamaica, Argentina, Uruguay, Colombia, south of Florida, as well as in the United States, Japan, Hawaii and Mozambique, while in Australia the species Uredo rangelli was reported by Carnegie et al. (Carnegie, A.J.; Lidbetter, J.R.; Walker, J.; Horwood, M.A.; Tesoriero, L.; Glen, M.; Priest, M.J.; Uredo rangelii, a táxon in the guayava rust complex, newly recorde don Myrtaceae in Austrália. Australasian Plant Pathology, v. 39, p. 463-466, 2010) parasitizing three Myrtaceae species. Acmena smithii was already reported as one of the host species of P. psidii in Australia in 2011 and 2012 [Carnegie, A.J.; Lidbetter, J.R. Rapidly expanding host range for Puccinia psidii sensu latu in Australia. Australasian Plant Pathology, v. 41, p. 13-29, 2012; Pegg, G.; Perry, S.; Carnegie, A.; Ireland, K.;
Giblin, F. Understanding myrtle rust epidemiology and host specificity to determine disease impact in Australia. Cooperative Research Centre for National Plant Biosecurity, 35p., 2012].

Studies with crossed inoculations have suggested a certain physiological variability within the species P. psidii [Aparecido, C.C.; Figueiredo, M.B.; Furtado, E.L. Grupos de variabilidade fisiológica em populações de Puccinia psidii. Summa Phytopathologica v. 29, n. 3, p. 234-238, 2003].

Pathogenicity in Acmena smithii was proven by means of inoculations into healthy plants. Thus, urediniospores collected from affected Acmena smithii plants were sprayed, by using a hand sprayer, at the concentration of $2.6 \times 10^{4}$ urediniospores $\mathrm{mL}^{-1}$, on 10 healthy seedlings. The plants were kept in a humid chamber during 24 hours in the dark, at $20 \pm 2^{\circ} \mathrm{C}$. After those 24 hours, they were kept under 12-hour photoperiod. At 15 days after inoculation, typical rust symptoms were noted in the inoculated plants (Figs. $1 D$ and $E$ ). Controls remained asymptomatic. Analysis under stereomicroscope and microscope revealed globose and oval urediniospores with echinulation on the outer walls (Fig. $1 F$ ), measuring 28.48 x $24.89 \mu \mathrm{m}$. Teleomorphic phase was not observed. This is the first report of Puccinia psidii Winter affecting Acmena smithii in Brazil. 